\title{
The Political Economy of the Higher Education Contribution Scheme
}

\author{
Bruce Chapman and Timothy Hicks
}

\section{$1 \quad$ Introduction}

In 1989 the Australian government adopted the world's first national income contingent student loan (ICL) system, then known as the Higher Education Contribution Scheme (HECS). What follows is a documentation and analysis of the issues important to an understanding of the political and policy environment of this financing reform. A critical motivating factor for the chapter is that closely related versions of HECS have now been implemented in around eight other countries and such systems look set to be adopted in several others very soon ${ }^{1}$. Thus the lessons drawn from what happened 28 years ago in Australia are highly likely to be relevant to perceptions of the role of political forces in policy reform well beyond this experience.

At the outset it is instructive to separate two aspects of the policy reform: the decision by the government to re-introduce tuition charges, which had been abolished in 1974; and the choice of an ICL instead of the adoption of normal (at the time, pervasive) approach to higher education financing, involving the use of time-based repayment loans (usually financed by banks). ICLs differ from "normal" loans in that repayments are only required if and only when a debtor's future income exceed a specified level.

In terms of the politics of the matter, it is the re-introduction of tuition charges in Australia that warrants the most attention, but with respect to the contribution to international economic policy it is the inaugural adoption in Australia of an ICL which is of much greater interest. This is because tuition charges were commonplace internationally, even in 1989, but a national ICL had not previously existed.

Tuition charge policy cannot be properly understood without an economically informed context. Consequently, we begin in Section 2 with an analysis of the economics of higher education financing; this provides a conceptual template and context to an understanding of the policy and political issues. This section adopts the separation of HECS into two issues as suggested above, with much of the analysis being concerned with an understanding of the costs and benefits of different forms of student loans systems.

Section 3 provides a brief chronology of Australian higher education financing in the period from fee abolition in 1974 to the introduction of HECS, which serves as necessary background to the political factors behind the 1989 changes. These are considered in some depth in Section 4, which in an important sense is the major contribution of the chapter, with the focus being on the political forces behind the re-introduction of tuition fees, rather then the adoption of ICL. The section describes aspects of related political forces in operation at

\footnotetext{
${ }^{1}$ In June 2017 the government of Colombia took the first legislative steps towards ICL reform.
} 
the time, which were generally working against the reintroduction of tuition fees in any form. The process can be described reasonably well as the "Labor Cabinet versus the Rest", with the Rest including some parts of the trade union movement, student representative bodies, and critical components of the Commonwealth bureaucracy. The reasons behind the successful adoption of the new arrangements by Labor are documented, and the relevance of the Australian debate to contemporary higher education financing changes in many other countries; it is clear that many of these countries are now facing very similar conjunctions of political and budgetary circumstances as were the case in Australia in the late 1980s.

\section{Higher Education Financing: Conceptual Issues}

\section{2 (i) The Case for a Tuition Charge}

In many countries in the past and in a minority of European countries at present ${ }^{2}$ students are allowed to enrol in higher education free of charge, which means that taxpayers subsidise close to 100 per cent of the direct costs of public universities. In some countries (such as Australia) students are provided with means-tested income support grants, and in others loans of different types are available for student income support (such as New Zealand and England). In a situation in which the costs of higher education are paid by the government, students face no upfront costs, and the difficulties associated with obtaining credit from banks, explained fully below, are less important; however so-called 'free' higher education has become distinctly unfashionable over the last 25 years, with a significant number of countries replacing zero-tuition-fee policies with charges on the direct beneficiaries, the students, including Australia (1989), New Zealand (1991), and England (2005).

There are two reasons for the introduction of tuition fees in public sector universities over the last several decades in many countries. First, governments have generally sought to increase the number of university places and in a world of fiscal parsimony, have required new sources of revenue to allow this to happen. Second, policy-makers have increasingly recognised that a no-charge university system is regressive, since such an arrangement is funded by all taxpayers (the majority of whom are not university graduates), delivering benefits to students who are more likely to have come from higher income family backgrounds and who receive on average considerable private rates of return to the investment.

These arguments have underpinned the case for a contribution from students and, in combination with the general agreement concerning the existence of positive social spillovers from higher education (see Chapman and Lounkaew, 2015), a taxpayer subsidy as well (Barr, 2001; Chapman, 2006). An important question that then arises is: is there a role for government beyond the provision of the subsidy?

\footnotetext{
${ }^{2}$ Including Germany, Sweden and Denmark.
} 


\section{2 (ii) Higher Education Financing: Why do we need student loans?}

An understanding of this issue is facilitated through consideration of what would happen if there were no higher education financing assistance involving the public sector. That is, a government that is convinced that there should be a part-subsidy for higher education, could simply provide the appropriate level of taxpayer support to higher education institutions, and then leave market mechanisms to take their course. Presumably this would result in institutions charging students tuition fees up-front on enrolment.

However, there are major problems with this arrangement, traceable in most instances to the potent presence of risk and uncertainty. The essential point is that educational investments are risky, with several sources of uncertainty (Barr, 2001; Palacios, 2004; Chapman et al., 2014). First, enrolling students do not know fully their capacities for (and perhaps even true interest in) the higher education discipline of their choice. This means that they cannot be sure that they will graduate; in Australia, for example, around 20-25 per cent of students end up without a university qualification (Cardak, 2015.

Second, even given that university completion is expected, students will not be aware of their likely relative success in the area of study. This will depend not just on their own abilities, but also on the skills of others competing for jobs in the area.

Third, even if students know the value of an investment based on current returns, there is uncertainty concerning the future value of the investment. The labour market - including the labour market for graduates in specific skill areas - is undergoing constant change; what looked like a good investment at the time it began might turn out to be a poor choice when the process is finished. Finally, many prospective students, particularly those from disadvantaged backgrounds, may not have much information concerning graduate incomes, due in part to a lack of contact with graduates.

These uncertainties are associated with important risks for both borrowers and lenders. A critical point is that if the future incomes of students turn out to be lower than expected, the individual is unable to sell part of the investment to re-finance a different educational path. For a prospective lender, a bank, the risk is compounded by the reality that in the event of a student borrower defaulting on the loan obligation, there is no available collateral to be sold, a fact traceable in part to the illegality of slavery. And even if it were possible for a third party to own and sell human capital, its future value might turn out to be quite low taking into account the above-noted uncertainties associated with higher education investments.

It follows that, left to itself - and even with subsidies from the government to cover the presumed value of externalities - the market will not deliver propitious higher education outcomes. Prospective students judged to be relatively risky, and/or those without loan repayment guarantors, will not be able to access the financial resources required for both the payment of tuition fees and to cover income support. Markets left alone cannot deliver 
equality of educational opportunity because those without collateral - the poor - will be unable to participate.

These capital market failures were first recognised by Friedman (1955) who suggested as a possible solution the use of a graduate tax or, more generally, the adoption of approaches to the financing of higher education involving graduates using their human capital as equity. The notion of "human capital contracts" developed from there and is best explained and analysed in Palacios (2004).

In the absence of the widespread availability of such human capital contracts, governments in almost all countries intervene in the financing of higher education. There are currently two major forms that this intervention takes: Time Based Repayment Loans (TBRL) and ICL.

\section{2 (iii) Student Loans: TBRL}

A possible solution to the capital market problem associated with the funding of higher education is used in many countries, such as the US, Canada and Japan. It involves the institutions charging up-front fees but with TBRL guaranteed by government in the event of default for both tuition fees and income support being made available to students on the basis of means testing of family incomes. Public sector support usually (for example, in Canada) takes two forms: the payment of interest on the debt before a student graduates; and the guarantee of repayment of the debt to the bank in the event of default. Arrangements such as these are designed to facilitate the involvement of commercial lenders, and the fact that they are internationally a common form of government financial assistance would seem to validate their use.

With a TBRL, banks do not need borrowers to have collateral because the public sector assumes the risks and costs of default. However, solving the problem of the provision of finance from the perspective of the banks is not the end of the story - TBRLs raise two problems for borrowers. They are that loans requiring repayment on the basis of time rather than capacity to pay are associated with both default risk and the prospect of future financial hardships related to borrowers' repayment difficulties. These issues are now considered in turn.

When loans have repayment obligations that are fixed with respect to time they are thus not sensitive to an individual's future capacity to repay. This raises the prospect of default for some borrowers, which means damage to a debtor's credit reputation and thus eligibility for other loans, such as for a home mortgage (Barr, 2001; Chapman, 2006). Thus, in anticipation of potential credit reputation loss, some prospective students may prefer not to take the default risk of borrowing because of the high potential costs. The possible importance of this form of "loss aversion" is given theoretical context in Vossensteyn and de Jong (2004).

There is a distributional issue related to the evidence concerning which students actually default. Dynarski (1994) uses the National Post-Secondary Student Aid Study for the US and finds strong evidence that experiencing low earnings after leaving formal education is a 
strong determinant of default. Importantly, borrowers from low-income households and minorities are more likely to default, as are those who do not complete their studies. An important implication of these findings is that some poor prospective students might be averse to borrowing from banks and thus choose not to enrol because of the risk of default, although there is little empirical evidence available on this issue.

It would be an exaggeration to suggest that students with bank loans have no alternative other than to default in circumstances in which they are unable to meet their repayment obligations. In the US, for example, borrowers have some (quite) limited potential to defer loan repayments if they are able to demonstrate that their financial situation is unduly difficult, and in some cases this might lead to temporary loan forgiveness. However, there is a maximum period for which this can be done of only 2 years and there would certainly generally be no expectation that any TBRL takes into account a debtor's capacity to repay.

There is some evidence related to the costs to governments of defaults from TBRL in terms of lost future loan repayment revenue, which usually and simplistically takes the form of reporting the percentage of borrowers who fail to maintain repayments and are therefore considered to be in default. Chapman and Lounkaew (2016) document these data for the TBRL systems in the US, Canada, Thailand and Malaysia, with the default incidence ranging from around 15 per cent for Canada, 20-30 percent for the US, but up to about 60 per cent in Thailand and Malaysia. Since governments effectively have to pay the debt in the event of a default, these costs to government explain why TBRLs are rationed and typically are available to only around half of the prospective student population ${ }^{3}$.

A related, and arguably the biggest, problem for students with TBRLs concerns possible consumption difficulties associated with fixed repayments which, by definition, are not influenced by a borrower's capacity to pay. If the expected path of future incomes is variable, a fixed level of a debt payment must be associated with a non-zero variance of disposable (after debt repayment) incomes. This raises the extremely important issue of so-called "repayment burdens". The repayment burden (RB) in any period $t$ is the issue, and is defined as follows:

$$
\text { Repayment Burden = Loan Repayment/Income ... (1) }
$$

RBs are the critical issue associated with comparisons between loan systems. The reason is that, at any given level of income, the higher is the proportion of that income that needs to be allocated to the repayment of a loan, the lower must be disposable income. In other words, for low income debtors a TBRL must mean lower utility than would be the case with an ICL.

The essential point is that lower student loan debtor disposable incomes with a TBRL have the two mortgage-type loan problems: repayment hardship and higher default probabilities. Whereas ICLs have RBs set at a maximum by law, and so far internationally are never more

\footnotetext{
${ }^{3}$ This is the case in the US and Canada for example.
} 
than 10 percent, RBs for TBRLs are unique for each individual borrower at any point in time and while they can in theory be close to zero for high income debtors, they can also be well over 100 per cent for very low income people with high debts .

There is by now considerable empirical analysis of RBs associated with TBRLs in many different countries (see for example, Chapman et al. (2010), Chapman and Sinning (2011), and Chapman and Dearden (2016), including with respect to Vietnam, Thailand, Indonesia, Germany and the US. These analyses show the impact of student loan repayment obligations for the whole distribution of graduate incomes by age and sex, a major improvement over previous analyses which focused on RBs only at the means of graduate incomes.

From this literature the results show that graduates in the bottom 25 per cent of the lifecycle income distribution of graduates have particularly high RBs in developing countries. For example, for the bottom quartiles of graduate incomes by age and sex in Vietnam, RBs can be as high as 85 percent, and even graduates in the top 25 per cent of the earnings distribution in this country would have to allocate about 15 percent of their income in the first ten years to repay the debt. In Thailand, where the student loan scheme has a large public subsidy, RBs for the bottom quartile of earners range from 25 per cent to 30 per cent. In Indonesia, for the lowest earning quartile, the simulation of a typical TBRL scheme reveals that RBs would vary from around 40 percent in a relatively high income area (Java), to around 85 percent in a relatively low income area (Sumatra). Importantly and to make this point more generally, even in developed countries graduates in the bottom parts of the earnings distribution can also face high repayment burdens, ranging from 50-60 percent for public sector lawyers in the United States (Chapman and Lounkaew, 2015) to 70 percent for East German women (Chapman and Sinning, 2012).

These estimates reveal that TBRLs are universally associated with very high RBs for low income young graduates and thus imply significant problems of consumption hardship for many former students, and a concomitant high minority of prospective students facing defaults. Default, it should be emphasized, is very expensive for debtors because of the associated effects on individuals' credit reputations (Chapman, 2006). These points highlight the need for consideration of the alternative higher education financing option, ICL.

The major point in comparisons of TBRL and ICL is that, by design, RBs cannot be an issue for the latter. This is because the RBs for ICLs are set by law as part of the design of such systems. In Australia, New Zealand and England, for example, the maximum RB allowed with their ICL schemes are 8, 10 and 9 per cent of income respectively. The costs and benefits of ICLs are now considered in detail. 


\section{2 (iv) Student Loans: ICL}

The essential difference between ICLs and TBRLs is that the income contingent variety serve to protect former students who earn only low incomes; capacity to pay is the explicit feature of the approach. That is, ICL schemes provide a form of "default insurance", since debtors do not have to pay any charge unless their income exceeds a pre-determined level. And after the first income threshold of repayment is exceeded, ICL repayments are always capped at a fixed and low proportion of the debtor's annual income.

Effectively, ICLs offer consumption smoothing since there are no loan repayment obligations when incomes are low, and a greater proportion of income is remitted to repay the debt when incomes are high. The ICL system is very much like a progressive income tax arrangement, except that the obligation to pay finishes when the debt is repaid. As noted, these features of an ICL are very different to a TBRL, in which the costs of defaulting on the loan may be very high in terms of being denied access to other capital markets (most notably housing) through the damage to a borrower's credit reputation. The removal of repayment hardships and the related advantage of default protection via ICL repayment thus resolves basic problems for prospective borrowers inherent in TBRL.

While repayment hardship for graduates is arguably not an issue for ICLs, it is still the case that non-repayment of loans implies government costs for both loan arrangements. It is inevitable that there are unpaid debts associated with ICLs, mainly due to debtor incomes being insufficient for some former students to involve full repayment over the life-cycle. In Australia these amounts are continually estimated by a government unit, the Office of Doubtful Debt. The calculations reveal that unpaid debt is of the order of 15-20 per cent of total loan outlays. This should not be classified as "default", since no-one incurs such reputational damage, but rather some non-repayment should be considered to be an inevitable consequence and cost of the insurance aspect of an ICL.

For ICL it is of interest to consider as well the administrative costs. As emphasised by Stiglitz (2014), it is an advantage of ICLs that they can be collected very inexpensively, a feature he labels "transactional efficiencies". In this context, in 1994 the Australian Tax Office put the collection costs for HECS at less than 3 percent of yearly revenue and today, with higher debts, this figure is bound to be less than this from economies of scale. To this figure Chapman (2006) adds an estimate of the compliance costs for universities and comes up with a total administration financial outlay of about 5 per cent of yearly receipts, which can only be described as small. In collection terms the system seems to have worked well and there are apparently significant transactional efficiencies in the use of employer with-holding for the collection of debt. Calculations done for this paper with reference to Budget papers concerning collection costs for the English ICL reveal even lower costs there.

The reason for this transactional efficiency is that the collection mechanism simply builds on an existing and comprehensive employer with-holding of personal income tax and/or social security systems, and is essentially a public sector monopoly due to the government's legal 
privilege to require information concerning citizen's incomes; some part of the government's capacity to collect ICL debt is traceable to this legal jurisdiction. As well, there are major efficiencies with the system because the vast majority of citizens are subjected to employer with-holding. While this could change in the future, it is difficult to imagine that a commercial entity could collect ICL debt cheaply because public sector collection mechanisms related to income are pervasive.

\section{A Brief Chronology of Australian Higher Education Financing: 1974-19894}

3 (i) 1974 to 1985

Australian universities required students to pay fees until 1974. Even so, the vast majority were exempt from fee obligations through the receipt of scholarships awarded on the basis of academic merit. These took two forms: Commonwealth and Teachers' College Scholarships, and covered together around 75-80 per cent of those enrolled. Fees were abolished in 1974, meaning that from the early 1970s until the beginning of 1987 Australian universities were financed without any direct contribution from students.

\section{3 (ii) 1987}

This policy stance was changed at the end of 1986 by the then Labor government with the institution of the Higher Education Administration Charge (HEAC), a small up-front fee on all university students of $\$ 250$ in 1987 terms, a charge which did not vary with respect to either discipline or course load. In symbolic terms, the institution of HEAC was significant in that it represented government endorsement of the charging of fees, and thus set the scene for more radical reforms involving user pays.

The revenue raised from HEAC was trivial in comparison to the total costs of higher education - amounting to around 3 per cent only of teaching costs. So in 1987 and 1988 it remained the case that taxpayers provided practically all of the finances for higher education. At this time, a conjunction of forces made it inevitable that the government would move financing arrangements towards increased contributions from students, and these are examined in Section 4.

\section{3 (iii) The Beginnings of HECS in 1987}

In 1987 John Dawkins invited Bruce Chapman of the Australian National University and a co-author of this paper, to prepare a report outlining the costs and benefits of different approaches to the introduction of a user-pays higher education system for Australia. The report (Chapman, 1987), presented to the Minister in December 1987, examined several

\footnotetext{
${ }^{4}$ The discussion in this section follows Chapman and Nicholls (2014).
} 
financing mechanisms, including up-front fees with scholarships, up-front fees with government subsidised bank loans, and an income contingent charge system. The paper recommended the last of these, with repayments to be made via the income tax system and collected by employers.

The support offered for an income contingent arrangement in the report was essentially related to equity and access, compared to the likely implications of the many other possible alternatives (such as up-front fees with scholarships, or government-guaranteed commercial loans provided by banks). The economic reasoning in favour of ICL compared to the typical student loans system in operation internationally, TBRL have been examined in detail in Section 2.

Chapman (1987) did not provide unqualified support for an ICL with a caveat related to administrative complexity. The concern was that the collection agency needed to be aware of debtors' incomes over their lifetimes, and this would seem to necessitate the support and involvement of the income tax authority, the Australian Tax Office ${ }^{5}$. Since the ATO had not been consulted to this point it was not clear how, or if, an ICL might be made to work. For this and other reasons examined in Section 3 John Dawkins believed that the paper would have a difficult reception.

\section{3 (iii) The Wran Committee: 1988}

John Dawkins' concerns with the political and policy difficulties associated with including the Chapman's report as part of the government's Green Paper of reforms to higher education led him to rethink the tuition fees strategy. He decided to set up a committee chaired by a popular former NSW Labor premier, Neville Wran, with committee members Professor Bob Gregory and Dr Meredith Edwards, and Mr Michael Gallagher served as Secretary, to examine the relative merits of the options as presented in Chapman (1987). Chapman served as a consultant to the committee.

It was clear from the Terms of Reference, written by Chapman and David Phillips ${ }^{6}$, that the job of the Wran Committee was to assess the relative merits of different ways to design a student loans system, with there being no doubt that the Government would be reintroducing university fees:

\footnotetext{
${ }^{5}$ We are now aware that having the income tax authorities involved in the collection of an ICL is not essential; what is necessary is employer with-holding on the basis of income (Barr, Chapman, Dearden and Dynarski (2017).

${ }^{6}$ David Phillips served in John Dawkins' office at the time, and later became the Minister's Chief of Staff. 
"1. The Government is committed to expanding the capacity and effectiveness of the higher education sector and to improving access to higher education that are currently under represented. This goal has significant funding implications, as outlined in the Policy Discussion Paper on higher education. Given current and likely future budgetary circumstances, the Government believes that it is necessary to consider sources of funding involving the direct beneficiaries of higher education.

2. The Committee should develop options and make recommendations for possible schemes of funding which involve contributions from higher education students, their parents and employers. In developing options, the Committee should have regard to the social and educational consequences of the schemes under consideration."

Over around five months of meetings the Wran committee decided that the ICL was the preferred student loans system and in May 1988 released its report. It recommended that all Australian public university undergraduates should be required to pay a charge, with the amount in three bands determined by course costs. While the fee could be paid up-front, it was expected instead to be deferred ${ }^{7}$ through payments being made dependent on a debtor's income. Collection was to be made a legal requirement of employers, or compulsory for the self-employed.

The government accepted the basis of the policy recommendation, except that the charge was made uniform for all students, and was set at $\$ 1800$ per full-time year in 1989 dollars $^{8}$ and HECS became policy in 1989. The first repayment threshold was set at average weekly earnings of all employees, at around $\$ 70,000$ per annum in 2017 terms $^{9}$.

Labor lost power in 1996, but the new (Coalition) government maintained the essence of HECS. However, in 1997, charge levels were increased by about 40 per cent on average, differential charges by course were introduced ${ }^{10}$ and the first income threshold at which graduates began to repay their loans was decreased considerably, breaking the link with average weekly earnings. This decision was partially reversed in 2005, at which time the government also allowed some (very limited) price discretion.

\footnotetext{
${ }^{7}$ The deferral option is taken by about $85-90$ percent of students.

${ }^{8}$ Equivalent to about $\$ 3,700$ in 2016 terms.

9 This is higher than it is today, which is about $\$ 57,000$ per annum.

${ }^{10}$ However, the differential prices did not reflect course cots as recommended by Chapman (1987) and the Wran Committee report. Instead the new charges were set as to reflect both course cots and expected future incomes by discipline. This remains the case in 2017.
} 


\section{The Politics of HECS}

\section{4 (i) Introduction}

There are several important aspects of the politics behind the introduction of HECS. But as noted, it is useful to distinguish between two separate aspects of HECS: the re-introduction of tuition fees for university attendance; and the use of an ICL to facilitate the financing of these fees. Overwhelmingly the politics of HECS was dominated by the first issue, even though the most important aspect of the policy in terms of the eventual transformation of the way that student financing can be thought about was income contingent loan collection, not tuition fees as such.

This section begins with an explanation of the political and budgetary forces that lead the Labor government to reintroduce tuition fees. This is followed by an examination of the reactions during the debate of 1988 from other players in the politics at the time: the opposition Coalition; student and education unions, the Vice-Chancellors, and the broader union movement. It is of interest that with the exception of the peak body of Australian unions, the Australian Council of Trade Unions (ACTU), all special interest groups outside the Parliament were against the reintroduction of tuition fees, and within Parliament the opposition Coalition supported fees but to be accompanied by scholarships and not involving an ICL.

\section{4 (ii) Why Labor Wanted University Fees: Budgetary and Political Factors}

The main proximal driver of policy change in the Australian HE sector was a significant increase in Year 12 (the final year of high school) completion rates through the 1980s. This posed a policy problem as the HE system was not designed in such a way that it would or could respond. Consequently, there was no commensurate expansion in higher education places for this growing pool of high school graduates - resulting in the political problem of large and growing queues of qualified prospective students. If this was the problem, then the basic solution to it is fairly clear: expand the number of places. The political question, of course, is who would pay for it.

This distributive question points to the overarching structure within which the HECS policy was formulated. Our contention is that the Labor government perceived its own and/or the nation's macroeconomic position to be perilous enough that increases in taxation or government expenditure were out of the question. As Schwartz (1994) put it, Australia was one of a set of "small states in big trouble" 11 which, buffeted by the economic turmoil of the

${ }^{11}$ Schwartz's (1994) other states were Denmark, New Zealand, and Sweden. 
1970s, faced a new set of political economy imperatives in the 1980s. Faced with rising current account deficits, rising net foreign debt, and (for some) potentially unsustainable fiscal deficits, political actors became alarmed enough that they effectively restructured the broad sweep of macroeconomic, labour market, and welfare state policies.

While Schwartz's analysis is aimed at a broader swathe of government activity than just the HE sector, this same basic premise can be seen fairly clearly with respect to HECS. The Labor government was indeed concerned with macroeconomic management and associated fiscal balance and so was not prepared to spend the increased taxpayer resources necessary to finance additional university places. This position was likely heavily influenced by the government's concern to distinguish itself from the previous Labor government of 1972-1975 - broadly, and perhaps unfairly, considered to be a high tax and spend government with a poor record with respect to economic management.

Labor, then, politically scarred by their experience in government in the 1970s, had a strong incentive to develop and maintain a reputation for economic competence in the 1980s. The influence of the resulting "big trouble" frame of thinking was very clearly a political starting point for the policy-making process that led to HECS. Indeed, this is directly visible in the Terms of Reference to the Wran Committee, which note that, "Given current and likely future budgetary circumstances, the Government believes that it is necessary to consider sources of funding involving the direct beneficiaries of higher education". Put another way: the government believed that they were not able to raise more taxes or debt to pay for changes in HE policy.

It was not the only reason why a firm budget constraint was placed on HE policy-making, though. The other prominent reason relates to the distributive consequences of HE spending and the fact that the ALP were governing at the time. This points to the application of an influential strand of the political science literature that has focused on the importance of the partisan complexion of government. There are different although mutually compatible variants of this line of argument, but the essence of each is that the policy goals of different parties can be explained by either or both of the material interests of their core constituencies and their ideological orientations, with each typically leading to party placement on a leftright (re)distributive politics dimension. These types of logic have been applied to macroeconomic management in general (e.g. Hibbs, 1977; Alvarez et al, 1991), as well as higher education policy in particular (Ansell, 2008; Busemeyer, 2009; Garritzmann, 2016).

Application of these material interest and ideological partisanship logics to the HECS case follows rather easily. With a centre-left government in the form of Labor, we would expect to see egalitarian concerns and particular consideration of the material interests of those on lower incomes and from less-advantaged social classes. Indeed, that is exactly what we see in this case. At least two Cabinet ministers, John Dawkins (Minister for Employment, Education and Training) and Peter Walsh (Minister for Finance), were strongly in favour of student fees 
on grounds of equity. Their view was that a system that did not charge higher education students was regressive: after all, with a no charge system, universities were paid for by all taxpayers yet students on average both came from relatively privileged backgrounds and as graduates they received relatively high personal economic benefits. ${ }^{12}$ In this sense, the partisanship logic reinforces the "big trouble" structural constraint.

The partisanship logic also helps to explain why the HECS ultimately took the form of tuition fees financed by ICL. If one accepts that general taxation and government borrowing cannot be used to expand the HE sector, then the funding inevitably must come from the students, themselves. However, as the discussion in Section 2 above makes clear, there are different possible schemes under which this student funding could be sourced.

The least interventionist from the governmental point of view is simply to leave private markets - in the form of personal/family savings and/or private borrowing — to finance tuition fees. Quite clearly, this posed rather notably adverse distributive consequences for the ALP, whose core constituencies would have tended to struggle the most to thrive under such a student finance scheme. Again, as discussed in Section 2, the TBRL approach offers some improvements over this free-market option, but still suffers from adverse distributive consequences for the ALP and its constituencies as they are likely to face even greater hardship from the high RBs that are associated with such an approach. As should be clear, now, the ICL approach minimises these distributive difficulties as it comes with built-in insurance against adverse economic/life outcomes for graduates, outcomes that may be particularly salient to potential students drawn from the ALP's core constituencies.

This analysis leads us to conclude that partisanship has the potential to explain the most interesting feature of the HECS from a public policy point of view: that is, the adoption of ICL to finance the increase in tuition fees. Taken together with the "big trouble" logic, these two theoretical components have the power to explain why the ALP government sought to adopt the HECS as government policy. Most other agents strenuously opposed the movement.

\section{4 (iii) Understanding Political Opposition to HECS}

There was widespread concern and opposition to HECS, not the ICL, but the reintroduction of tuition charges. This can be illustrated schematically with reference to the Schwartz framework utilized above, now shown in Table 1, which draws together several dimensions of the political orientations that position the groups. 


\begin{tabular}{|c|c|c|c|c|c|}
\hline & & \multicolumn{4}{|c|}{ Distributive Preferences } \\
\hline & & \multicolumn{2}{|c|}{ HE Beneficiaries Pay } & \multicolumn{2}{|c|}{ Full Tax Base Pays } \\
\hline & & Progressive & Regressive & Progressive & Regressive \\
\hline \multirow{7}{*}{$\begin{array}{l}\text { Macroeconomic } \\
\text { View }\end{array}$} & "Big , & $\frac{\boldsymbol{F e e s}+\boldsymbol{I C L}}{\text { ALP Cabinet }}$ & $\frac{F e e s+T B R L}{\text { Coalition }}$ & \multicolumn{2}{|c|}{ N.A. } \\
\hline & \multirow{6}{*}{$\begin{array}{c}\text { "No } \\
\text { Problem" }\end{array}$} & $\underline{F e e s+I C L}$ & $\underline{F e e s+T B R L}$ & Free + Large & $\underline{\text { Free }+ \text { Small }}$ \\
\hline & & ACTU & & Expansion & $\underline{\text { Expansion }}$ \\
\hline & & & & Students' Union & \\
\hline & & & & $\begin{array}{c}\text { Tertiary } \\
\text { Education Unions }\end{array}$ & \\
\hline & & & & Vice Chancellors & \\
\hline & & & & ALP Left & \\
\hline
\end{tabular}

\section{Table 1}

\section{Theoretical Structure Showing How Macro-economic and Distributive Preferences Relate to HE Policy Preferences.}

The bottom two rows correspond to policy actors holding a macro-economic view of Australia as being in "big trouble" and having "no problem", respectively. The rightmost four columns, meanwhile, correspond to policy actors holding distributive preferences regarding the expansion of HE provision that imply that students (that is, HE beneficiaries) should pay for this extra university education (the first pair of columns) or that the costs should be spread across the full tax base (the second pair of columns).

Distributive preferences, as captured by the columns, are further sub-categorized as being "progressive" or "regressive" in order to capture the distribution of costs within the group of people who would pay for the HE expansion. For example, a preference for HE beneficiaries paying for $\mathrm{HE}$ expansion could correspond to a preference for the richer paying more to subsidize the poorer - that is, progressive funding. Alternatively, the HE beneficiary pays preference could come without any concern for differential access to credit to pay for university across the income distribution - i.e. regressive funding.

On the basis of the discussions above, we are able to make fairly clear logical connections between the various combinations of macro-economic views and distributive preferences that are possible within our framework. The bold-italic-underlined entries in Table 1 show what $H E$ policy preferences logically flow from these prior attitudes. Meanwhile, the plain-text entries in each cell indicate which of those HE policy preferences different actors and interest groups should hold, according to our theory, based on their macro-economic views and distributive preferences. Thus, the table allows us to combine presentation of our theoretical 
structure with some suggestive evidence as to how successful it is at explaining the broad political patterns in play during adoption of the HECS reform. The following points are offered in summary.

First of all, if one accepts the "big trouble" view, then financing expansion using the full tax base is ruled out as it would entail raising one of taxation or government borrowing. Hence, these two cells are filled with "N/A". Second, if one accepts "big trouble" and wishes HE beneficiaries to pay, then expansion must be financed by high fees to cover the cost. The progressivity/regressivity is then determined by the accompanying financing options for these fees, as explained above. However, the logical policy choices are different if one starts from the "no problem" macro-economic view. This opens up a compatible preference for the full tax base paying for expansion such that fees are not necessary. The question of progressivity/regressivity is then captured by the relative size of the expansion of university places, where larger expansion is more progressive as it will tend to draw in more students from lower down the socioeconomic distribution (Ansell 2008).

Finally, the combination of "no problem" and "students should pay" attitudes yields less clear-cut logical HE policy preferences. The students pay preference clearly tips towards the imposition of fees, but the prevailing view that government finances are capable of financing expansion suggests that there is likely to be an infusion of funding from this source, too not least because that accords with the existing funding model. Given that, we associate this pattern of attitudes with the presence of fees, albeit probably not as high as those in the corresponding "big trouble" cells as the budget constraint is not as tight. As before, progressivity/regressivity is resolved by preferences for access to credit to finance these fees.

The table also allows us to probe the effectiveness of the theoretical structure that we have proposed by indicating the expectations that we should have about the HE policy preferences of different actors involved in the policy process. That is to say, if we can identify the macroeconomic views and distributive preferences of these policy actors, then their HE policy preference should follow. We can then verify, empirically, whether these were indeed the policy preferences of these actors. As such, this procedure provides a kind of test of the theory in general, and so allows us to lend credibility (or not) to our claims about why the ALP Government actually chose the policy.

As discussed there are clear reasons to place the ALP Government in the top-left box of Table 1: they clearly accepted the "big trouble" view, which led to the HE beneficiaries pay position, and their relatively leftist orientation meant a progressive approach was preferred. As we know, the Fees + ICL policy was the one they went on to choose.

More interestingly, we can conduct the same process with other actors. A natural starting point is the opposition Coalition. From Parliamentary statements this group, too, clearly embraced the "big trouble" view, and the consequent "students should pay" position. 
However, their ideological and constituency commitments were such that a more regressive distributive preference was in place. Thus, our model predicts their preferred policy would be Fees + TBRL In fact, in Parliament, they supported the introduction of fees but not the ICL portion, just as our analysis would suggest.

There were also notable groups involved - or at least seeking to be involved - in the policy process who did not embrace the "big trouble" view, but rather subscribed to something closer to a position of "no problem". This opened the way for many of them to also prefer that HE expansion costs be borne by the full tax base, rather than students themselves. For the most part, this position was adopted by traditionally more distributively progressive organizations, and so our model suggests that they would each hold a preference for HE policy of the form: Free + Expansion. In this group, we include the students' union ${ }^{13}$, university employee unions ${ }^{14}$, and the left-/backbench-wing of the ALP'

We may also include university vice chancellors (VCs) in this category ${ }^{16}$. However, doing so points to the possibility of partial reverse causation operating through our model, at least for some groups. That is, for some of these HE-specific interest groups, it may well be the case that HE-specific policy preferences are causally prior to the macro-economic view being held, and possibly even to the distributive preferences. For example, VCs and university employee unions plausibly had a direct financial/organizational interest in expanding university places as much as possible (perhaps for reasons akin to those in Niskanen 1971). If they perceived ${ }^{17}$ that government funding was the best way to obtain this - and it is not selfevident that this should be true as fee-based university finance does not obviously imply lower levels of funding overall - then the "no problem" macro-economic view would be far more attractive as it would not rule out greater government spending. Note, however, that even if this was the logic for some actors in the process, it does not undermine the basic logical structure of the model that we propose here: rather it uses it in reverse.

There is a perfectly consistent pattern of attitudes which adopts the "no problem" view and the position that HE expansion should be financed by its beneficiaries, not the tax-payer as a whole. We see these positions as being consistent with the ACTU position, the memberships of which were not obviously going to be the beneficiaries of university expansion (either themselves or their children). Nonetheless, being largely distributively progressive organizations, we should expect them to adopt Fees + ICL. Indeed, Simon Crean, the Secretary of the ACTU, seconded John Dawkins motion at the ALP Conference in July 1988 which changed the party platform from the position that universities "should be free to

\footnotetext{
${ }^{13}$ For documentation of the position of the National Union of Students, see Chapman and Nicholls (2014).

${ }^{14}$ See Media release, FAUSA, 1988.

15 These points of view were common knowledge although not written down. Bruce Chapman chaired a Caucus sub-committee of the government in 1988 which was dominated by left-wing proponents of tuition-free universities. For party unity the issues could not be aired publicly.

${ }^{16}$ See AVCC, 1988.
} 
students" to that of "universities should be free for students at the point of entry" - precisely a move on the distributive dimension away from "full tax base pays". This then allowed the introduction of HECS.

Finally, it is interesting to briefly consider the more sparsely populated cells in Table 1 . The no-problem-beneficiary-regressive cell is not populated with any actors/groups as we did not identify any of note that held such a pattern of preferences. This should not be surprising as "no problem" view tended to be correlated with more left-wing/progressive political attitudes. Meanwhile, the no-problem-tax-base-regressive cell is also left empty. Logically, there are candidate groups for this cell, but we exclude them from the table as we lack adequate empirical evidence about their positions. Speculatively, then, we may suspect professional organisations - representing lawyers, doctors, accountants, and the like - could well have held views consistent with this cell. That is, to the extent that they had not subscribed to the "big trouble" frame, their interests were plausibly in keeping the supply of graduates into their professions under control (so as not to undermine salaries) and to continue with the practice of the full tax base subsidising their education.

Table 1, and the theoretical structure on which it is based, also point to some of the political difficulties that the ALP faced in ensuring the passage of the HECS reform. A notable coalition of interests - some of which would typically be associated with left-wing politics was lined up against the distributive implications of the policy. However, the model also makes clear to what extent these within-left divisions are effectively driven by differences over the "big trouble" versus "no problem" macro-economic view. Counter-factually, if we adjust the position of all of these leftist groups to one of acceptance of "big trouble", their preferred policy position would be predicted to be that which the government ultimately followed: Fees + ICL.

Just as our theoretical approach goes a way towards explaining the various features of the within-left political contestation over HECS, it also makes sense of the strategies that were employed to "sell" the policy to the public and elite interests, alike. First, in an effort to foster unity on the left, great emphasis was placed on a basic equity message whereby a no-charge system was highlighted as essentially regressive - in the sense that average taxpayers contribute to a scheme providing large private benefits to those who benefit from the subsidy. Moreover, not only was it clear that graduates do very well in the labour market, but it was also obviously the case that university students, on average, came from relatively advantaged backgrounds. The (arguably derogative, but statistically accurate) term used by Ministers Dawkins and Walsh in the selling of HECS was that not having a charge was "middle class welfare".

Second, political messaging emphasized the part of the proposed scheme that set the first income threshold of the HECS charge - i.e. the point at which those with ICLs would be required to start repayments - at the average earnings of all Australians working in the paid 
labour market. This allowed the government to neutralize opposition to the scheme on the basis of it being "unfair", since no graduate had to repay any of the debt unless they were receiving at least as much income as the taxpayers subsidizing most of their education.

Third, when the scheme was proposed, the government said that it would establish a trust fund. This fund was to receive all HECS revenue and the funds were to be used only for higher education purposes. In reality such a fund is not particularly meaningful given that HECS revenues in any given year would not exceed government expenditure on universities. Even so, at the time it probably served the political purpose of implying that HECS was principally a benefit for higher education. In fact, a formal trust fund was not established, though the government adopted the practice of reporting explicitly, on an annual basis, the revenue generated through HECS.

In summary, the Labor Cabinet believed it faced major political and budgetary pressures to reintroduce tuition charges, and took on this challenge despite very significant opposition from both within its own ranks, and with respect to important and vocal outside players. Even within Parliament, even though the opposition Coalition supported the reintroduction of fees this was done in a way that meant the ICL was not supported and this party voted against the Bill in the upper house. It would not have been passed except for the political acumen of John Dawkins $^{18}$, who made an extraordinary deal with a cross-bench party, the Australian Democrats.

\section{4 (iv) HECS and the International Higher Education Financing Reform}

After HECS was introduced there were similar debates in other countries concerning the introduction of university fees, and how best to do this. A full explanation and analysis of the circumstances involved in the adoption of HECS-type of reforms internationally is not possible here, but the countries that have reformed their systems in this direction are New Zealand (1992), Namibia (1996), England (1997), Ethiopia (2001), Thailand (for 2007 only), Hungary (2003), South Korea (2011) and the Netherlands (2016). In many of cases these countries moved from being tuition-fee-free to instituting charges, and in all cases the reforms involved the adoption of ICL.

In 2017 there are on-going and enthusiastic debates in other countries that seem destined eventually to introduce ICL, and these include Colombia (Sarna, 2017), Brazil (Nascimento, 2017) and Ireland (Chapman and Doris, 2016). As well, there is by now considerable research on student loan reform with respect to ICL in the US (Barr, Chapman, Dearden, Dynarski, 2016), Malaysia (Ismael, 2014), Japan (Armstrong and Masa, 2017) and China (Cai, Chapman and Wang). There is little doubt that the ALP's introduction of HECS has turned out to be a watermark reform with respect to international higher education financing.

\footnotetext{
${ }^{18}$ Personal correspondence.
} 


\section{Conclusion}

The adoption of HECS in Australia constitutes a radical economic policy reform, with the critical element being that this is the first national ICL. The economic case for ICL instead of TBRL is overwhelming and has been outlined above, with the insurance aspects of ICL apparent and highly desirable in terms of the protection of debtors from repayment hardship and default.

Most of the public discussion at the time, and the politics of Australian higher education reform, centred around the value or other wise of universities being tuition-fee-free, and we have attempted to understand and classify the positions of the major political agents with respect to the "big problem" framework of Schwartz. It is of interest that the opponents of the change seem to have been united in their stance against the imposition of tuition fees, although the political acumen of the Labor Cabinet at the time, particularly that of the Minister John Dawkins, was sufficient to overcome this.

\section{References}

Alvarez, R. M., Garrett, G. and Lange, P. (1991). "Government Partisanship, Labor Organization, and Macroeconomic Performance". American Political Science Review, 85, 539-556.

L. Andrews (1997), The Effect of HECS on Interest in Undertaking Higher Education, DEETYA, Canberra.

Ansell, B. (2008), "University Challenges: Explaining Institutional Change in Higher Education". World Politics, 60: 189-230.

P. Aungles, I. Buchanan, T. Karmel and M. MacLachlan (2002), HECS and Opportunities in Higher Education, Department of Education Science and Training from Draft, Canberra, http://www.dest.gov.au/NR/ rdonlyres/67F0E451-009F-43D5-837A-

7851E2E13973/731/hecs.pdf.

Jeff Borland (2002),"New Estimates of the Private Rate of Return to University Education in Australia", Melbourne Institute Working Paper No. 14/02.

Busemeyer, M. R. (2009). "Social democrats and the new partisan politics of public investment in education". Journal of European Public Policy, 16: 107-126.

Buly Cardak (2015), "Graduates, Dropouts and Slow Finishers: The Effects of Credit Constraints on University Outcomes", Oxford Bulleting of Economics and Statistics, November.

Bruce Chapman and T. T. Chia, (1988), "An Economic Analysis of the Higher Education Contribution Scheme of the Wran Report", Economic Analysis and Policy, vol. 18, no. 3, 
(September): 171-85.

Bruce Chapman and Chris Ryan, (2005), "The Access Implications of Income Related Charges for Higher Education: Lessons from Australia", Economics of Education Review, vol. 24, no. 5: 491-512.

Bruce Chapman and Timothy Higgins (2013), "The Costs of Unpaid Higher Education Contribution Scheme Debts of Graduates Working Abroad", Australian Economic Review, Vol.46 (3) (September): 286-299.

Bruce Chapman and Kiatanantha Lounkaew (2015), "'Estimating the Value of Externalities in Higher Education", Higher Education, Vol. 70: 767-785.

M. Edwards, C. Howard and R. Miller (2001), Social Policy, Public Policy: From Problem to Practice, Allen \& Unwin, Sydney.

Ross Finnie and Alex Usher (2006), "The Canadian Experiment in Cost-Sharing and its Effects on Access to High Education, 1990-2002", in Pedro N Teixeira, D Bruce Johnstone, Maria J. Rosa and J. J. Vossensteijn (eds), Cost-Sharing and Accessibility in Higher Education: A Fairer Deal?, Springer, Dordrecht, The Netherlands: 79-105.

J. Garritzmann, (2016)., The Political Economy of Higher Education Finance: The Politics of Tuition Fees and Subsidies in OECD Countries, 1945-2015. Palgrave MacMillan.

D. A. Hibbs (1977). "Political Parties and Macroeconomic Policy", American Political Science Review, 71: 1467-1487.

J. Lomax-Smith, L. Watson and B. Webster (2011), Higher Education Base Funding Review, Final Report, DEEWR, Canberra.

Niskanen, W. A. (1971), Bureaucracy \& Representative Government, New Brunswick, NJ: Aldine.

Schwartz, H. (1994). "Small States in Big Trouble: State Reorganization in Australia, Denmark, New Zealand, and Sweden in the 1980s". World Politics, 46: 527-555.

N. Wran, Report of the Committee on Higher Education Funding (1988), AGPS, Canberra, (27 April). 